\title{
MENSTRUAL CYCLE WORSENING OF EPILEPTIC SEIZURES IN WOMEN WITH SYMPTOMATIC FOCAL EPILEPSY
}

\author{
Ana Carolina Belini Bazán, Maria Augusta Montenegro, \\ Fernando Cendes, Li Li Min, Carlos A.M. Guerreiro
}

\begin{abstract}
Introduction: Ho monal fluctuation is responsible for worsening of epileptic seizures during the menstrual cycle. Objective: To identify irregularities in the menstrual cycles of women with mesial temporal lobe epilepsy (MTLE) and extratemporal focal epilepsy (ETFE) and correlate the frequency of seizures during the menstrual cycles. Method: We evaluated prospectively women in the menacme with MTLE and ETFE. Calendars were provided for these patients, and they were asked to mark their seizure frequency according to the menses. Calendars were reviewed in each routine medical appointment. Results: Thirtynine patients with MTLE and 14 with ETFE were evaluated. We reg ist ered 211 cycles in the patients with MTLE and 49 in those with ETFE. Irregular menstrual cycles were found in $28(28 / 39,71.7 \%)$ patients with MTLE and $6(6 / 14,42.8 \%)$ with ETFE $(p=0.052)$. Premenstrual seizure worsening was observed in $46(21.8 \%)$ patients with MTLE and $9(18.3 \%)$ with ETFE ( $p=0.596)$. Menstrual worsening was observed in $47(22.2 \%)$ patients with MTLE and $15(30.6 \%)$ with ETFE ( $p=0.217)$. Ovulatory worsening was observed in $36(17 \%)$ patients with MTLE and $13(26.5 \%)$ with ETFE $(p=0,126)$. Catamenial worsening was observed in $58(27.4 \%)$ of the patients with MTLE and in $17(34.7 \%)$ of the patients with ETFE $(p=0.315)$. Conclusion: The rewas no difference between the group of patients with MTLE and ETFEregarding the frequency of irregular cycles and seizure worsening during the premenstrual, menstrual, catamenial or ovulatory periods.
\end{abstract}

KEY WORDS: epilepsy, catamenial, temporal lobe epilepsy, extra-temporal epilepsy, menstrual cycle.

\section{Piora de crises epilépticas durante o período menstrual em mulheres com epilepsia focal sinto- mática}

RESUMO - Introdução: Admite-se que a flutuação hormonal seja a responsável para a piora de crises epilépticas no período catamenial. Objetivo: Identificar irregularidades nos ciclos menstruais de mulheres com epilepsia de lobo temporal mesial (ELTM) e epilepsia focal extratemporal (EFET); e relacionar a frequencia de crises durante o ciclo menstrual. Método: Avaliamos mulheres na menacme, que apresentem quadro clínico laboratorial compatível com ELTM e EFET. Foram fornecidos calendáriospara estas pacientes e instruídas para preenchimento correto da menstruação e das crises epilépticas e serão revistos em cada consulta médica rotineira. Resultados: Foram avaliadas 39 pacientes com ELTM e 14 com EFET. Registramos 211 ciclos nas pacientes com ELTM e 49 nas com EFET. Cidos menstruais irregulares foram apresentados por $28(71,7 \%)$ pacientes com ELTM e $14(42,8 \%)$ com EFEP $(p=0,052)$. Piora pré-menstrual foi observada em $46(21,8 \%)$ pacientes com ELTM e $9(18,3 \%)$ com EFET $(p=0,596)$. Piora menstrual foi observada em $47(22,2 \%)$ pacientes com ELTM e $15(30,6 \%)$ com EFET ( $p=0,217)$. Piora ovulatória foi observada em $36(17 \%)$ pacientes com ELTM e $13(26,5 \%)$ com EFET $(p=0,126)$. Piora catamenial foi observada em $58(27,4 \%)$ das pacientes com ELTM e em $17(34,7 \%)$ das pacientes com EFET $(p=0,315)$. Conclusão: Não houve diferença entre os grupos de pacientes com ELTM e EFET quanto à freqüência de ciclosirregu la rese piora das crises nos períodos pré-menstrual, menstrual, catamenial ou ovulatório.

PALAVRAS-CHAVE: epilepsia, catamenial, epilepsia de lobo temporal, epilepsia extratemporal, ciclo menstrual.

Epilepsy has an estimated prevalence between 1 and $1.8 \% \%^{1-3}$. The incidence of epilepsy in women is similar to that in men. Anovulatory cycles are more frequent in women with epilepsy. In addition, it seems that epileptic seizures are more frequent in anovulatory cycles than in normal cycles ${ }^{4}$. There a re reports that up to $50 \%$ of women with epilepsy in the menacme present worsening of seizures through the menstrual cycle ${ }^{5}$.

Herzog et al. ${ }^{6}$ described three standards of sei-

Department of Neurology - University of Campinas (FCM/UNICAMP), Campinas SP, Brazil. Supported by FAPESP.

Received 16 November 2004, received in final form 21 March 2005. Accepted 9 May 2005.

Dr. Carlos A.M. Guerre i ro - Department of Neurology, FCMIUNICAMP, Caixa Postal 6111 - 13083-970 Campinas SP - Brasil. E-mail: guerreiro@fcm.unicamp.br 
zu reworsening related to diff erent periods of the menstrual cycle: a) seizures that occur during the three days before menses and on the first three days of menses; b) seizures that occur close to the middle of the cycle, before the ovulation between the $8^{\text {th }}$ and $14^{\text {th }}$ days; c) seizures that are frequent between the $8^{\text {th }}$ day of a cycle and the $2^{\text {nd }}$ day of the next; these cycles are anovulatory. This last standard is more difficult to identify, comparing to those that occur in normal menstrual cydes. Experimental studiesshowed that estrogen isepileptogenic and progesterone protects against seizures'. Epileptiform activity is observed during menses, on the days that precede it and in the middle of the menstrual cycle. Patients with both partial and generalized epilepsies present catamenial seizure worsening 8 .

The objective of this study was to identify irregularities in the menstrual cycles of women with mesial temporal lobe epilepsy (MTLE) and extratemporal focal epilepsy (ETFE), and correlate the frequency of seizures during menstrual cycle.

\section{METHOD}

Women in fertile age were evaluated. Patients were seen at the epilepsy dinic of our University Hospital.

MTLE was characterized according to dinical end elect roencephalographic criteria established by the ILAE'. Patients presented seizures with epigastric sensation, nausea, autonomic signs, eructation, pallor, facial flush, activity break, pupillary dilatation, fear, panic and olfactory and gustative hallucination ${ }^{9}$. Neuroimaging evaluation by high resolution showed hippocampal atrophy and hyperintense $\mathrm{T} 2$ signal indicating mesial temporal sclerosis.

ETFE was based on dinical, EEG and neuroimaging findings of frontal, parietal and occipital epilepsy ${ }^{10,11}$.

Every patient was submitted to a questionnaire concerning gynecological and obstetrical antecedents and detailed menstrual history. In addition they were asked to fill out of the calendar regarding the menstrual period.

We considered as irregular cycles the ones shorter than 26 days and longer than 32 days of duration.

Inclusion criteria - a) Women in the menacme with MTLE and ETFE diagnosis according to the criteria of the ILAE for at least one year ${ }^{9}$;b) MRI and EEG investigation perf o rmed at our institution; c) Good compliance to the treatment and available telephone for contact if needed; d) Attendance to clinical follow-upsregularly; e) Fill out the calendar properly; f) Absence of hormonal therapy or the use of valproate; g) Signature of informed consent submitted and approved by the Research Ethics Committee of the institution.

Analysis of the data - The analysis of the data was based on the different periods of the menstrual cycle. The average of crises per day was calculated for each pe riod and compared to other days of the cyde. We estimated worsening when the average of seizure/day in a determined period of the cycle was higher than the either average of the other days or twice or three times the average.

Table 1. Patients with extratemporal focal epilepsy.

\begin{tabular}{|c|c|c|c|c|c|c|c|c|}
\hline $\mathrm{N}^{*}$ & $\begin{array}{l}\text { Age } \\
\text { (years) }\end{array}$ & $\begin{array}{c}\text { Menarc } \\
\text { (years) }\end{array}$ & $\begin{array}{c}\text { First } \\
\text { seizure }\end{array}$ & Type & $\begin{array}{c}\text { Epileptiform } \\
\text { EEG }\end{array}$ & $\begin{array}{c}\text { Normal } \\
\text { EEG }\end{array}$ & MRI & Drugs in use \\
\hline 1 & 40 & 12 & 19 years & SPS/CPS/GTCS & YES & NO & normal & LTG 400mg/CBZ 1000mg \\
\hline 2 & 35 & 15 & 11 years & SPS/CPS/GTCS & YES & YES & L sulcus atrophy & CBZ 1600mg/CLB $10 \mathrm{mg}$ \\
\hline 3 & 25 & 13 & 4 years & CPS & YES & NO & double cortex & $\begin{array}{l}\text { CBZ 1200mg/NGB 750mg/ } \\
\text { TIORAZIDE 50mg }\end{array}$ \\
\hline 4 & 20 & 13 & 4 years & GTCS & YES & NO & bilateral occip gliosis & CBZ/TPM/CLN \\
\hline 5 & 26 & 14 & 1y 8month & SPS/CPS/GTCS & NA & NA & $\begin{array}{c}\text { PNH } \\
\text { RTO cortical }\end{array}$ & CLB 10/TOPAMAX 100 \\
\hline 6 & 32 & NA & 8 years & SPS/CPS/GTCS & YES & NO & displasy & PB 300mg/CLB 40mg \\
\hline 7 & 40 & 12 & 9 years & SPS & YES & NO & normal & CBZ 600mg \\
\hline 8 & 22 & 14 & 6 years & SPS/CPS & YES & NO & R frontal gliosis & CBZ 600mg/ CLBI 40mg \\
\hline 9 & 28 & 14 & 14 years & SPS/CPS/GTCS & YES & YES & LOR dural AVMF & CBZ 400mg \\
\hline 10 & 34 & 11 & 4 years & SPS/CPS. & YES & NO & neurocisticercosis & OXC 2100/CLB 40 \\
\hline 11 & 36 & 10 & 9 years & SPS/CPS/GTCS & YES & NO & calosotomy & CBZ 1200mg/NPA 1500mg/CLB 20 \\
\hline 12 & 30 & 9 & 27 years & SPS/CPS/GTCS & NO & YES & NA & OXC $600 \mathrm{mg} / \mathrm{PHT} 100 \mathrm{mg}$ \\
\hline 13 & 41 & 12 & 13 years & SPS/CPS/GTCS & YES & NO & CDMF in LFR & OXC $1800 \mathrm{mg}$ \\
\hline 14 & 25 & 13 & 7 years & CPS & YES & NO & normal & CBZ 1200mg/CLB 60 mg/AMT 75mg \\
\hline
\end{tabular}

SPS, simple partial seizure; CPS, complex partial seizure; GTCS, generalized tonic-clonic seizures; HÁ, hipocampal atrophy; R, right; L, left; NA, not available; AVMF, arterial-venous malformation; R- region; O- occipital; T- temporal; F-frontal; CDMF, cortical development malformation; Cort, co rtical; PNH, periventricular nodular heterotopy; CBZ, carbamazepine; CLB, clobazam; OXC, oxcarbazepine; LGT, lamotrigine; PHT,phenytoin; VPA, valproate; PB, phenobarbital; ETX, etossuximide; TPM, topiramate; CLN, clonazepam; AMT,amitriptiline, MRI, magnetic resonance imaging. 
Table 2. Patients with temporal lobe epilepsy.

\begin{tabular}{|c|c|c|c|c|c|c|c|c|}
\hline $\mathrm{N}^{*}$ & $\begin{array}{c}\text { Age } \\
\text { (years) }\end{array}$ & $\begin{array}{c}\text { Menarc } \\
\text { (years) }\end{array}$ & $\begin{array}{l}\text { First } \\
\text { seizure }\end{array}$ & TypeYPE & $\begin{array}{l}\text { Epileptiform } \\
\text { EEG }\end{array}$ & Normal EEG & MRI & Drugs in use \\
\hline 1 & 47 & 15 & 15 years & SPS/CPS/GTCS & NO & YES & RHA & CBZ 1200mg/CLB 20mg \\
\hline 2 & 42 & 15 & 3 years & CPS & YES & YES & LHA & CBZ 1200mg/CLB 40mg \\
\hline 3 & 25 & 12 & 14 years & SPS/CPS/GTCS & YES & NO & RHA & CBZ 600 mg/LGT 200mg/CLB 30mg \\
\hline 4 & 37 & 13 & 13 years & SPS/CPS & NA & NA & NA & PHT 200mg/ CLB 10 mg \\
\hline 5 & 36 & 13 & 4 years & SPS & YES & NO & LHA & CBZ 1400mg/CLB 20mg \\
\hline 6 & 39 & 13 & 20 years & SPS/CPS/GTCS & YES & NO & LHA & CBZ 600mg \\
\hline 7 & 33 & 15 & 18 years & SPS/CPS & YES & NO & LHA & CBZ 800mg/CLB 20mg \\
\hline 8 & 39 & 14 & 8 years & CPS/GTCS & YES & NO & LHA & CBZ 800mg/CLB 20mg \\
\hline 9 & 36 & 13 & 2 years & CPS/GTCS & YES & NO & LHA & $\begin{array}{c}\mathrm{CBZ} 1200 \mathrm{mg} / \mathrm{NPA} 600 \mathrm{mg} / \mathrm{LGT} \\
250 \mathrm{mg} / \mathrm{CLB} 20 \mathrm{mg}\end{array}$ \\
\hline 10 & 22 & 11 & 14 years & CPS/GTCS & YES & NO & LHA & CBZ 600mg \\
\hline 11 & 24 & 12 & NA & SPS/CPS/GTCS & YES & YES & RHA & PB 150mg \\
\hline 12 & 38 & 18 & 20 years & SPS/CPS/GTCS & NO & YES & normal & CBZ 1000mg \\
\hline 13 & 20 & 13 & 15 years & SPS/CPS & NO & YES & LHA & CLB 20mg/CBZ1000mg \\
\hline 14 & 20 & 12 & 10 years & SPS/CPS/GTCS & YES & YES & LHA & CBZ 1200mg \\
\hline 15 & 43 & 10 & 1 year & SPS/CPS & YES & YES & RHA & OXC 2100 mg/CLB 30mg \\
\hline 16 & 42 & 12 & 2 years & CPS/GTCS & YES & YES & RHA & CLB 30mg/OXC 600mg \\
\hline 17 & 37 & 13 & 3 years & SPS/CPS & YES & YES & RHA & CBZ 800mg/CLB 10mg \\
\hline 18 & 38 & 13 & 24 years & SPS/CPS/GTCS & YES & YES & RHA & PB 250 mg/CLB 20mg \\
\hline 19 & 48 & 12 & 26 years & SPS/CPS/GTCS & YES & NO & NA & CBZ 600mg \\
\hline 20 & 42 & 14 & 7 years & SPS/CPS/GTCS & YES & YES & LHA & CBZ 600mg \\
\hline 21 & 30 & 10 & 11 years & SPS/CPS/GTCS & NO & YES & LHA & CBZ 1300mg/CLB 40mg \\
\hline 22 & 42 & 14 & 18 years & SPS & YES & NO & NA & ETX 750mg \\
\hline 23 & 30 & 12 & 4 years & CPS/CPS/GTCS & YES & NO & NA & CBZ 1100mg/CLB 20mg \\
\hline 24 & 33 & 13 & 1 year & SPS/CPS/GTCS & YES & YES & RHA & CBZ 1200mg/CLB 30mg \\
\hline 25 & 46 & 13 & 15 years & CPS & YES & YES & LHA & CBZ 1000mg/CLB 20mg \\
\hline 26 & 17 & 10 & 7 years & CPS/GTCS & YES & NO & LHA & CLB 20mg/ CBZ 1200mg \\
\hline 27 & 39 & 12 & 11 years & CPS & YES & NO & RHA & CBZ1200mg \\
\hline 28 & 40 & 10 & 2 years & SPS/CPS/GTCS & YES & NO & RHA & CBZ 1200mg/CLB 10mg \\
\hline 29 & 33 & 11 & 25 years & SPS/CPS/GTCS & YES & YES & RHA & CBZ 800mg \\
\hline 30 & 28 & 14 & 1 year & CPS & YES & NO & LHA & CBZ 1000mg \\
\hline 31 & 36 & 13 & 13 years & SPS/CPS & YES & YES & RHA & CBZ 1000mg/CLB $10 \mathrm{mg}$ \\
\hline 32 & 38 & 11 & 14 years & CPS & YES & NO & cerebellar atrophy & $\begin{array}{l}\text { CLB 40mg/CBZ 900mg/ } \\
\text { NORTRIPTILINE 60mg }\end{array}$ \\
\hline 33 & 28 & 12 & 7 years & SPS/CPS/GTCS & YES & NO & RHA & CBZ 1200mg/ CLB 40mg \\
\hline 34 & 34 & 14 & 28 years & SPS/CPS/GTCS & YES & NO & normal & OXC 600mg/CLB 20mg \\
\hline 35 & 30 & 12 & 4 years & SPS/GTCS & YES & YES & LHA, neurocisticercosis & CBZ 800mg/CLB $10 \mathrm{mg}$ \\
\hline 36 & 40 & 14 & 3 years & SPS/CPS/GTCS & YES & NO & RHA & CBZ 1200mg \\
\hline 37 & 42 & 15 & 11 mounths & CPS/GTCS & YES & NO & RHA & CBZ $1200 \mathrm{mg}$ \\
\hline 38 & 22 & 11 & 16 years & SPS/CPS/GTCS & NO & YES & Normal & CBZ 400mg/CLB 10mg \\
\hline 39 & 35 & 12 & 4 years & SPS/CPS/GTCS & YES & NO & BilateralHA & CBZ 400mg/NPA 2000mg \\
\hline
\end{tabular}

SPS, simple partial seizure; CPS, complex partial seizure; GTCS, generalized tonic-clonic seizures; HA, hipocampal atrophy; R, right; L, left; NA, not available; AVMF, arterial-venous malformation; CBZ, carbamazepine; CLB, dobazam; OXC, oxcarbazepine; LGT, lamotrigine; PHT,phenytoin; VPA, valproate; PB, phenobarbital; TPM, topiramate; CLN, clonazepam; MRI, magnetic resonance imaging.

Premenstnal period: three days before the first day of the cycle (the menstruation first day).

Menstrual period: period when there was bleeding until the fifth day.

Ovulatory period: period of 5 days, 14 days before the menstruation \pm 2 days.

Catamenial period: premenstrualperiod + menstrual period.

Catamenial worsening: three-fold increase in seizure frequency in relation to the other days of the cycle.
Statistical analysis was performed using the ChiSquare test.

\section{RESULTS}

Thirty-nine patients with MTLE and 14 with ETEF were evaluated (Tables 1 and 2). We registered 211 cycles in patients with MTLE and 49 in those with ETFE.

I regular menstrual cycles were presented by $28(28 / 39,71.7 \%)$ patients with MTLE and 6 (6/14, 
Table 3. Presence of regular and irregular menstrual cycles, and registered seizures in patients with ETFE.

\begin{tabular}{ccccc}
\hline Identification & $\begin{array}{c}\text { \#of registered } \\
\text { cycles }\end{array}$ & $\begin{array}{c}\text { \#of registered } \\
\text { seizures }\end{array}$ & $\begin{array}{c}\text { regular cycle } \\
26-32 \text { days }\end{array}$ & $\begin{array}{c}\text { irregular cycle } \\
<26 \text { ou >32days }\end{array}$ \\
\hline 1 & 2 & 21 & 1 & 1 \\
2 & 1 & 0 & 0 & 1 \\
3 & 8 & 114 & 4 & 4 \\
4 & 4 & 71 & 3 & 1 \\
5 & 5 & 2 & 5 & 0 \\
6 & 1 & 7 & 1 & 0 \\
7 & 2 & 17 & 2 & 0 \\
8 & 2 & 282 & 2 & 0 \\
9 & 5 & 0 & 5 & 0 \\
10 & 2 & 404 & 2 & 0 \\
11 & 4 & 83 & 3 & 1 \\
12 & 2 & 7 & 2 & 0 \\
13 & 5 & 0 & 5 & 0 \\
14 & 6 & 26 & 3 & 3 \\
\hline
\end{tabular}

42.8\%) with ETFE ( $p=0.052)$. Information related to seizure counting and regular and irregular menstrual cydesare in Table 3 and 4. Menstrual worsening was observed in 46 cycles $(21.8 \%)$ of patients with MTLE and 9 cycles (18.3\%) of patients with ETFE $(p=0.596)$. Menstrual worsening was observed in 47 cycles $(22.2 \%$ ) of patients with MTLE and 15 cycles $(30.6 \%)$ of patients with ETFE $(p=0.217)$. Ovulatory worsening was observed in 36 cycles ( $17 \%$ ) of patients with MTLE and 13 cycles $(26.5 \%)$ of patients with ETFE $(p=0.126)$.

Catamenial increasing of seizures (seizures predominantly on the pre and menstrual cycles) was observed in 58 cycles $(27.4 \%)$ of patients with MTLE and in 17 cycles (34.7\%) of patients with ETFE $(p=0.315)$. Catamenial worsening (according to our definition of three-fold increase in seizure frequency in relation to the other days of the cyde) waspresent in $29(13.7 \%)$ of the patients with MTLE and $4(8.1 \%)$ of the patients with ETFE $(p=0.290)$

\section{DISCUSSION}

Catamenial epilepsy refers to seizures related to menstrual cycle and affects approximately $m$ $10-70 \%$ of women with epilepsy, depending on the definition of worsening ${ }^{6}$. Experimental studies demonstrated that the ovarian steroid hormones affect the neuronal excitability, that way they give support to a biologic base for these fluctuations in epilepsy that occur in association with the menstruation, from the menarche to the menopause ${ }^{12-19}$. The low levels of progesterone in the menses, the rising of estrogen level in the ovula- tion and low levels of progesteroneduring the luteal phase of anovulatory cycles are among the several factors that precipitate the catamenial epilepsy. These factors result in the elevation of the estrogen/progesterone ratio ${ }^{20}$. A decrease on serum levels of the antiepileptic drugs on the days that precede the menstruation, can also contribute for the premenstrual exacerbation of the seizures. It is supposed that the lower serum levels of antiepileptic drugs is due to an increase in their metabolism by the hepatic microsomal enzyme system that involves the gonadal steroid metabolism ${ }^{19}$.

Mattson et al. ${ }^{4}$ reported an increase in seizure frequency during the anovulatory cycle, mainly during the estrogen peak. Jansen and Vaemet ${ }^{21}$ related larger incidence of amenorrhea in women with MTLE than in the general population of women. Our data showed that one third of patients evaluated presented catamenial seizure worsening; if we accept the definition proposed by Herzog et al. ${ }^{6}$ - higher frequency of seizure on the catamenial (pre + menstrual) period than that of the rest of the cycle.

We evaluated the menstrual disorders in patients with MTLE and ETFE because of the fact that these conditions are well-defined electro-clinic syndromes ${ }^{10,11,22,23}$. These two forms of lesional epilepsies, frequently refractory to the antiepileptic drug (AED) treatment, were evaluated in women who did not use hormone therapy or sodium valproate. It is confirmed that the use of valproate increases the occurrence of anovulatory cydes, mainly in wo- 
Table 4 - Presence of regular and irregular menstrual cycles, and registeredseizures in patients with MTLE.

\begin{tabular}{|c|c|c|c|c|}
\hline Identification & $\begin{array}{c}\text { \#of registered } \\
\text { cycles }\end{array}$ & $\begin{array}{c}\text { \#of registered } \\
\text { seizures }\end{array}$ & $\begin{array}{l}\text { regular cycle } \\
26-32 \text { days }\end{array}$ & $\begin{array}{l}\text { irregular cycles } \\
<26 \text { ou }>32 \text { days }\end{array}$ \\
\hline 1 & 5 & 5 & 2 & 3 \\
\hline 2 & 6 & 13 & 1 & 5 \\
\hline 3 & 4 & 86 & 2 & 2 \\
\hline 4 & 7 & 25 & 3 & 4 \\
\hline 5 & 3 & 0 & 3 & 0 \\
\hline 6 & 4 & 10 & 4 & 0 \\
\hline 7 & 19 & 132 & 13 & 6 \\
\hline 8 & 6 & 41 & 6 & 0 \\
\hline 9 & 6 & 20 & 3 & 3 \\
\hline 10 & 2 & 0 & 2 & 0 \\
\hline 11 & 17 & 52 & 1 & 16 \\
\hline 12 & 2 & 0 & 1 & 1 \\
\hline 13 & 13 & 3 & 3 & 3 \\
\hline 14 & 4 & 94 & 3 & 1 \\
\hline 15 & 11 & 11 & 6 & 5 \\
\hline 16 & 6 & 20 & 3 & 3 \\
\hline 17 & 6 & 30 & 5 & 1 \\
\hline 18 & 1 & 0 & 0 & 1 \\
\hline 19 & 3 & 9 & 3 & 0 \\
\hline 20 & 5 & 6 & 2 & 3 \\
\hline 21 & 5 & 0 & 5 & 0 \\
\hline 22 & 2 & 166 & 1 & 1 \\
\hline 23 & 2 & 10 & 2 & 0 \\
\hline 24 & 2 & 10 & 1 & 1 \\
\hline 25 & 7 & 13 & 3 & 4 \\
\hline 26 & 3 & 50 & 3 & 0 \\
\hline 27 & 2 & 12 & 0 & 2 \\
\hline 28 & 3 & 0 & 2 & 1 \\
\hline 29 & 10 & 1 & 8 & 2 \\
\hline 30 & 5 & 4 & 5 & 0 \\
\hline 31 & 5 & 13 & 5 & 0 \\
\hline 32 & 3 & 30 & 2 & 1 \\
\hline 33 & 3 & 0 & 2 & 1 \\
\hline 34 & 12 & 46 & 11 & 1 \\
\hline 35 & 5 & 7 & 2 & 3 \\
\hline 36 & 9 & 212 & 5 & 4 \\
\hline 37 & 5 & 36 & 3 & 2 \\
\hline 38 & 2 & 2 & 2 & 0 \\
\hline 39 & 3 & 11 & 1 & 2 \\
\hline
\end{tabular}

men with generalized idiopathic epilepsy ${ }^{24,25}$. Theoretically, the group of patients with limbic lesions (MTLE) would be more inclined to hormonal dysfunctions originated from the influence of limbic structures on the hypothalamus and hypophysis and the consequent hormonal disorder and pos sible influence on the menstrual cycle.

Anovulatory cycles occur in 14 to $39 \%$ on the diverse forms of epilepsy in women ${ }^{26,27}$. According to the methodology utilized, we did not evaluate the patients under the endocrinologic point of view (if the irregular cycles observed were anovulatory or not). Nevertheless, it is known that $11 \%$ of women with epilepsy have cycles with intervals out of the period of 21-35 days, which is larger than what is expected on the general population, about $2 \%{ }^{26,28,29}$. We adopted the period of $26-32$ days for the definition of regular cydes based on the Herzog and Friedman's findings ${ }^{26}$, who found significant increase of anovulatory cycles out of this period. It 
is known that the irregular cycles have higher probability of being anovulatory ${ }^{26}$. The irregular cycle finding has clinic importance because the frequency of epileptic seizures is higher in these cycles, ${ }^{6,20}$. In addition, the incidence of reproductive endocrine d i so rdersis higher in these women ${ }^{30-32}$, part i cul arly the polycystic ovary syndro me $\mathrm{m}^{32-34}$. These disturbancesare associated with an increase of the infertility rate, migraine, emotional disturbances, resistance to insulin, cardiovascular disease and cancer ${ }^{35}$. The real role of the irregular or anovulatory cycles in these patients and their medical dimension need complementaryinvestigations.

A recent study about long-term reproductive endocrine health in young women with epilepsy during puberty have shown that $56 \%$ patients taking antiepileptic medication, $32 \%$ of patients without drugsand $38 \%$ normal control presented irregular menstrual cycles. They defined irregular cycle if the intermenstnal variation was $>7$ days or the cycle duration was $>35$ days or $<21$ days, at least once during the preceding 6 months. In the same study, Mikkonen et al..$^{36}$ found that polycystic ovary syn d rome was more common in patients on medication (38\%, mainly valproate) than in patients without medication (6\%) or in controls ( $11 \%$ ). These authors ${ }^{36}$ proposed that irregular menses may be considered an adverse event of antiepileptic drug treatment, particularly in puberty.

Therewas no seizure worsening difference on the premenstrual, menstrual, catamenial or ovulatory periods in the two groups of patients we studied. This is a prelimi narysudy and a larger sample should be evaluated in order to confirm our findings.

\section{REFERENCES}

1. Marino R Jr, Cukiert A, Pinho E. Aspectos epidemiológicos da epilepsia em São Paulo: um estudo da prevalência. Arq Neuropsiquiatr 1986; 44:243-254.

2. Fernandes JG, Schimidt MI, Monte TL, et al. Prevalence of epilepsy: the Porto Alegre study. Epilepsia 1992;33(Suppl 3)S:132.

3. B o rges MA. Prevalência urbana da epilepsia: estudo populacional na cidade de São José do Rio Preto-Brasil. Tese. São José do Rio Preto, 2002.

4. Mattson RH, Kamer JA, Caldwell BV, et al. Seizure frequency and menstrual cycle: a clinical study. Epilepsia 1991;22:242.

5. Millichap JP. Systemic electrolyte and neuroendocrine mechanisms. In Jasper HH, Ward AA Jr., Pope A (eds). Basic mechanisms of the epilepsies. Boston: Little, Brown, 1969:709-726.

6. Herzog AG, Klein P, Ransil BJ. Three patterns of catamenial epilepsy. Epilepsia 1997;38:1082-1088.

7. Lagothetis J, Harner R. Electrocortical activation by estrogens. Arch Neurol 1960;3:290-297.
8. Marcus EM, Watson CW, Goldman PL. Effects of steroids on cerebral electrical activity. Arch Neurol 1966;15:521-532.

9. Comission on Classification and Terminology of the International League Against Epilepsy. Proposal for revised classification of epilepsies and epileptic syndromes. Epilepsia 1989;30:389-399.

10. Foldvary N. Symptomatic focal epilepsies. In Wyllie E (ed). The treatment of epilepsy: principles and practice. Philadelphia: Lippincott Williams \&Williams, 2001:467-474

11. Williamson PD, Jobst BC. Selection of candidates for extratemporal resection. In Wyllie $\mathrm{E}$ (ed). The treatment of epilepsy: principles and practice. Philadelphia: Lippincott Williams \&Williams, 2001:1095-1114.

12. Abassi F, Krumholz A, Kittner SJ, et al. Effects of menopause on seizures in woman with epilepsy. Epilepsia 1999;40:205-210.

13. Diamantopoulos N, Crumrine PK. The effect of puberty on the course of epilepsy. Arch Neurol 1986;43:873-876.

14. Guerre i roCAM, Ramos MC. Premenstrual seizure increase: influence of age, duration of disease, seizure frequency, previous complaint of perimenstrual accentuation, EEG and CT scan findings. Arq Neuropsiquiatr 1991;49:27-32.

15. Guerreiro CAM. Período ovulatório e crises epilépticas. Arq Neuropsiquiatr 1991;49:198-203.

16. Silveira DC, Guerreiro CAM. Início de crises epilépticas na menarca. Arq Neuropsiquiatr 1991;49:434-436.

17. Ha rden CL, Pulver MC, Ravdin L, et al. The effects of menopause on the course of epilepsy. Epilepsia 1999;40:1402-1407.

18. Zahn C. Catamenial epilepsy: clinical aspects. Neurology 1999;53 (Suppl.1):S34-S37.

19. Morral M. Managing epilepsy in women across the reproductive cycle. Monograph. A CME Monograph for Neurologists, Secaucus, NJ: Projects in Knowledge, 2001.

20. BackstromT. Epileptic seizures in women related to plasma estrogen and progesterone during the menstrual cycle. Acta Neurol Scand 1976; 54:321-347.

21. Jansen I, Vaernet K. Temporal lobe epilepsy follow up investigation of 74 temporal lobe resected patients. Acta Neurochir 1977;37:173-200.

22. Engel J Jr. Update on surgical treatment of the epilepsies. Neurology 1993;43:1612-1617.

23. Pedley T. Neurobiologia da epilepsia de lobo temporal. In Guerreiro CAM, Guerreiro MM (eds). Epilepsia. São Paulo:Lemos Editorial, 1996: 19-29.

24. Mor rell MJ. Effects of epilepsy on women's re p roductive health. Epilepsia 1998;39(Suppl 8):S32-S37.

25. Stephen LJ, Kwan P, Shapiro D, Dominickzak M, Brodie MJ. Hormone profiles in young adults with epilepsy treated with sodium valproate or lamotrigine monotherapy. Epilepsia 2001;42:1002-1006.

26. Herzog AG, Friedman MN. Menstrual cycle interval and ovulation in women with localization-related epilepsy. Neurology 2001;57:2133-2135.

27. Morrel MJ, Giudice L, Flynn KL, et al. Predictors of ovulatory failure in women with epilepsy. Ann Neurol 2002;52:704-711.

28. Vollman RF. The menstrual cycle. In Friedman E (ed). Major problems in obstetrics and gynecology. Philadelphia: WB Saunders, 1977:1-193.

29. Trealoar AE, Boynton RE, Borghild GB, et al. Variation of human menstrual cycle through reproductive life. Int J Fertil 1967;12:77-126.

30. Bilo, L, Meo R, Nappi C, et al. Reproductive endocrine disorders in women with epilepsy with primary generalized epilepsy. Epilepsia 1988;29:612-619.

31. Herzog AG, Russel V, Vaitukaitis JL, et al. Neuroendocrine dysfunction in temporal lobe epilepsy. Arch Neurol 1982;39:135-139.

32. Herzog AG, Seibel MM, Schomer DL, et al. Reproductive endocrine disorders in women with partial epilepsy. Arch Neurol 1986;43:341-346.

33. Genton P, Bauer J, Duncan S, et al. On the association between valproate and polycystic ovary syndrome. Epilepsia 2001;42:295-304.

34. Isojärvi JIT, Tauboll E, Tapanainen JS, et al. On the association between valproate and polycystic ovary syndrome: a response and an alternative view. Epilepsia 2001;42:305-310.

35. Herzog AG, Schachter SC. Valproate and the polycystic ovary syndrome: final thoughts. Epilepsia 2001;42:311-315.

36. Mikkonen K, Vainionpää LK, Pakarinen AJ, et al. Long-term reproductive endocrine health in young women with epilepsy during puberty. Neurology 2004;62:445-450. 